Abstracta Iranica Iranica

Revue bibliographique pour le domaine irano-aryen

Volume 25 | 2004

Comptes rendus des publications de 2002

\title{
«The Sasanian Complex at Bandian: Palace or Dynastic Shrine ». BAI 11, (1997 [2000]),
} pp. 193-196.

Rémy Boucharlat

\section{(2) OpenEdition}

1 Journals

Édition électronique

URL : http://journals.openedition.org/abstractairanica/4331

DOI : 10.4000/abstractairanica.4331

ISSN : 1961-960X

Éditeur :

CNRS (UMR 7528 Mondes iraniens et indiens), Éditions de l'IFRI

\section{Édition imprimée}

Date de publication : 15 mai 2004

ISSN : 0240-8910

Référence électronique

Rémy Boucharlat, « «The Sasanian Complex at Bandian: Palace or Dynastic Shrine ». BA/ 11, (1997 [2000]), pp. 193-196. », Abstracta Iranica [En ligne], Volume 25| 2004, document 89, mis en ligne le 15 mars 2006, consulté le 25 septembre 2020. URL : http://journals.openedition.org/abstractairanica/ 4331 ; DOI : https://doi.org/10.4000/abstractairanica.4331

Ce document a été généré automatiquement le 25 septembre 2020.

Tous droits réservés 


\title{
"The Sasanian Complex at Bandian: Palace or Dynastic Shrine ». BAI 11, (1997 [2000]), pp. 193-196.
}

\author{
Rémy Boucharlat
}

1 Le complexe de Bandian ne ressemble à aucun monument connu, ce que le fouilleur, M. Rahbar, a bien souligné dans sa première étude parue en Iran puis dans St. Ir. 27/2, (1998). Les reliefs en stuc portant des scènes princières variées et les inscriptions publiées par R. Bashshash Kanzaq, puis réétudiées et interprétées différemment par Ph. Gignoux dans la même livraison de St. Ir. indiquent un commanditaire de haut rang - un roi ? - mais ne nous éclairent pas sur la fonction. L'interprétation par le fouilleur d'une des salles comme un lieu de dépôt d'ostodans (ostothèques) ne facilite pas la compréhension du monument. Cette hypothèse que M. Rahbar avance avec prudence dans un autre article publié en persan, et également à paraître dans St. Ir., me paraît peu plausible.

\section{INDEX}

Thèmes : 3.2.3. Séleucides, Parthes et Sassanides

\section{AUTEURS}

RÉMY BOUCHARLAT

CNRS - Lyon 